\title{
Chagas disease in the State of Pernambuco, Brazil: analysis of admissions and mortality time series
}

\author{
Doença de Chagas no Estado de Pernambuco, Brasil: análise de séries históricas das internações \\ e da mortalidade
}

\section{Suellen Carvalho de Moura Braz ${ }^{1,2}$, Myllena de Fátima Alheiros Dias Melo ${ }^{1,2}$, Virginia Maria Barros de Lorena ${ }^{1,2}$, Wayner Vieira de Souza ${ }^{1}$ and Yara de Miranda Gomes ${ }^{1,2}$}

\begin{abstract}
Introduction: A time series study of admissions, deaths and acute cases was conducted in order to evaluate the context of Chagas disease in Pernambuco. Methods: Data reported to the Information Technology Department of the Brazilian National Health Service between 1980 and 2008 was collected for regions and Federal Units of Brazil; and microregions and municipalities of Pernambuco. Rates (per 100,000 inhabitants) of hospitalization, mortality and acute cases were calculated using a national hospital database (SIH), a national mortality database (SIM) and the national Information System for Notifiable Diseases (SINAN), respectively. Results: The national average for Chagas disease admissions was 0.99 from 1995 to 2008. Pernambuco obtained a mean of 0.39 in the same period, with the highest rates being concentrated in the interior of the state. The state obtained a mean mortality rate of 1.56 between 1980 and 2007, which was lower than the national average (3.66). The mortality rate has tended to decline nationally, while it has remained relatively unchanged in Pernambuco. Interpolating national rates of admissions and deaths, mortality rates were higher than hospitalization rates between 1995 and 2007. The same occurred in Pernambuco, except for 2003. Between 2001 and 2006, rates for acute cases were 0.56 and 0.21 for Brazil and Pernambuco, respectively. Conclusions: Although a decrease in Chagas mortality has occurred in Brazil, the disease remains a serious public health problem, especially in the Northeast region. It is thus essential that medical care, prevention and control regarding Chagas disease be maintained and improved.
\end{abstract}

Keywords: Chagas disease. Pernambuco. Hospitalization. Mortality. Acute cases.

\section{RESUMO}

Introdução: Foi realizado estudo de séries históricas de internações, óbitos e casos agudos por doenças de Chagas objetivando avaliar o contexto desta enfermidade em Pernambuco. Métodos: Foram coletados dados notificados de 1980 a 2008 ao Departamento de Informática do Sistema Único de Saúde (DATASUS/MS) para regiões e unidades federativas do Brasil, microrregiões e municípios pernambucanos. As taxas (por 100.000 habitantes) de internações, mortalidade e casos agudos foram obtidas por consulta ao Sistema de Informações Hospitalares (SIH), Sistema de Informação sobre Mortalidade (SIM) e Sistema de Informações de Agravos de Notificação (SINAN), respectivamente. Resultados: A média de internações nacional por doença de Chagas ficou em 0,99 no período de 1995 a 2008. Pernambuco, neste intervalo, apresentou média de 0,39, com as maiores taxas concentradas no interior do estado. Este estado obteve média de óbitos 1,56 entre 1980 e 2007, valor inferior a brasileira $(3,66)$. O país demonstrou declínio de óbitos na análise de tendência, com Pernambuco encontrandose em estado estacionário para esta taxa. Interpolando os dados referentes a internações e óbitos, evidenciou-se mortalidade em valores superiores as taxas de internações nacionais, entre 1995 e 2007. O mesmo fato ocorreu em Pernambuco, exceto em 2003. Entre 2001 e 2006, a taxa de casos agudos foi de 0,56 e 0,21 respectivamente para Brasil e para Pernambuco. Conclusões: Mesmo o Brasil demonstrando redução na mortalidade, a doença permanece como grave problema de saúde pública, principalmente no nordeste. Desta forma, é fundamental a manutenção e melhoria das ações de atenção médica, controle e prevenção já existentes.

Palavras-chaves: Doença de Chagas. Pernambuco. Internações hospitalares. Mortalidade. Casos agudos.

1. Centro de Pesquisas Aggeu Magalhães, Fundação Oswaldo Cruz, Recife, PE. 2. Programa Integrado de Doença de Chagas, Fundação Oswaldo Cruz, Rio de Janeiro, RJ.

Address to: Dra. Yara de Miranda Gomes. CPqAM/FIOCRUZ. Caixa Postal 7472. Av. Moraes Rego s/n, 50670-420 Recife, PE, Brasil.

Phone: 5581 2101-2500 ramal 2593; Fax: 5581 3453-1911

e-mail: yara@cpqam.fiocruz.br

Received in $25 / 11 / 2010$

Accepted in 07/02/2011

\section{INTRODUCTION}

Despite significant advances in vector control, Chagas disease still represents a worldwide public health problem. The disease, whose causative agent is Trypanosoma cruzi, occurs from the Southern United States to Southern Argentina and Chile and infects 15 to 16 million individuals in Latin America, with approximately 75 to 90 million exposed to infection ${ }^{1}$. In 2005, it was estimated that nearly 2 million individuals were infected in Brazil, which was the expected number for the whole of Central America².

The epidemiological context in the Northeastern states of Brazil presents a number of specific features. National surveys of prevalence and distribution of vectors, conducted between 1975 and 1980, have shown that the region has the second highest number of infected individuals and the highest triatomine infestation rates ${ }^{3-5}$. In 1996, the Chagas Disease Control Program of the National Health Foundation (Fundação Nacional de Saúde) of the Ministry of Health (Ministério da Saúde, FNS/MS) collected 290,576 triatomines in Brazil, 69.2\% (201,156 triatomines) of which were found in the northeast region. In the State of Pernambuco, $2.43 \%$ of the 8,431 insects collected as part of this survey were infected with T. cruzi $i^{6}$. In a serological survey of human Chagas disease, the Superintendents of Public Health Campaigns (Superintendências de Campanhas de Saúde Pública, SUCAM) determined a prevalence of $4.2 \%$ in Brazil from 1975 to 1981, with Pernambuco showing a prevalence of $2.8 \%{ }^{4}$. Another serological survey conducted among schoolchildren between 1997 and 1998 determined a prevalence of $0.08 \%$ in the Northeast region and $0.05 \%$ in the State of Pernambuco ${ }^{6}$. Relevant data have been provided by a survey at the Pernambuco Blood Center (Hemocentro de Pernambuco, HEMOPE), where $0.17 \%$ of blood donation candidates tested positive for anti-T. cruzi IgG between 2002 to $2007^{7}$. Despite the decline in prevalence, these data indicate that the parasite reamins in circulation in human hosts and suggests the need for continuous surveillance. 
In an effort to combat the dissemination of Chagas disease in the 1990s, Southern Cone countries implemented the Action to eliminate Triatoma infestans ${ }^{8}$. This reinforced the actions to control transmission of the disease that had been in existence since 1975 in Brazil ${ }^{9}$. As a result, in 2006, the Pan American Health Organization/World Health Organization considered Brazil free of transmission of Chagas disease via its main vector (T. infestans) and transfusion of blood and blood products ${ }^{10}$. However, the presence of secondary vector species such as Triatoma sordida, Triatoma brasiliensis and Panstrogylus megistus $^{11}$, together with other forms of transmission, such as the ingestion of contaminated food ${ }^{12-14}$ and congenital transmission ${ }^{15}$, have given rise to concern that the disease may re-emerge.

This study aims to evaluate Chagas disease in Pernambuco and Brazil. For this, data regarding hospital admissions, deaths and acute cases of this disease reported to the Information Technology Department of The Brazilian National Health Service (Departamento de Informática do Sistema Único de Saúde, DATASUS/MS) between 1980 and 2008 were collected.

\section{METHODS}

This is a descriptive study using data from the following national databases: the Hospital Information System (Sistema de Informações Hospitalares, SIH), the Mortality Information System (Sistema de Informação sobre Mortalidade, SIM) and the Information System for Notifiable Diseases (Sistema de Informações de Agravos de Notificação, SINAN) of the DATASUS/MS.

Information regarding hospital admissions for American trypanosomiasis includes the Hospital Admission Authorizations (Autorizações de Internações Hospitalares, AIH) for acute and chronic cases according to place of residence, from 1995 to 2008. The AIH reports all authorizations for SUS cash reimbursements for hospitalization. The available mortality data by acute and chronic Chagas disease, also according to place of residence, cover the period from 1980 to 2007. SIH and SIM data were grouped according to the ninth and tenth editions of International Statistical Classification of Diseases and Related Health Problems (ICD-9 and ICD-10). Cases of acute Chagas disease according to place of residence, reported to SINAN, cover the period from 2001 to 2006 . The evaluation period for hospital admissions, mortality and acute cases includes the available ranges in SIH, SINAN and SIM, respectively.

The analysis considered rates for hospital admissions, mortality and detection of acute cases of Chagas disease occurring in regions and federal units of Brazil; and in microregions and municipalities of Pernambuco, per 100,000 inhabitants. Rates were calculated using population data provided by DATASUS/MS. In order to a provide time series of mortality rates for Brazil, the Northeast region and Pernambuco, linear regression models were constructed for tendency analysis, where y (mortality rate) $=\alpha+\beta x$ year. Additionally, the hospitalization and mortality rates for Chagas disease were compared.

The Hospital Information System (SIH) and the Mortality Information System (SIM) were consulted regarding 18 microregions of the State of Pernambuco: Alto Capibaribe, Araripina, Brejo Pernambucano, Garanhuns, Itamaracá, Itaparica, Mata Meridional, Mata Setentrional, Médio Capibaribe, Petrolina, Recife, Salgueiro, Sertão do Moxotó, Suape, Vale do Ipanema, Vale do Ipojuca, Vale do Pajeú and Vitória de Santo Antão.
The data were collected in December 2009, tabulated and analyzed using TabWin 32, statistical package for the Social Sciences (SPSS) 8.0 and Excel Office 2007.

Since this study uses secondary data from the public domain, it does not disclose the individual identity of the individuals involved, thus no ethical considerations arise.

\section{RESULTS}

According to SIH data, 24,130 hospital admissions for trypanosomiasis were reported between 1995 and 2008 in Brazil. Of these, 3,555 occurred in the northeast and 443 in Pernambuco. The mean national rate for admissions in this period was 0.99 per 100,000 inhabitants. The increase in this rate, which reached 2.09 in 2003, should be highlighted; however, rates have declined strongly in recent years, with only 0.76 reported admissions $/ 100,000$ inhabitants in 2008. The Northeast had an average rate of 0.5 and, like other regions, showed a peak in 2003, with 1.3 admissions (Figure 1).

Of the Northeastern states, Pernambuco ranked eighth in terms of average hospitalizations, with $0.39 / 100,000$ inhabitants from 1995 to 2008. Pernambuco, like the other states in this region and the country as a whole, showed a decline in reported admissions subsequent to 2003. It is worth noting that the State of Alagoas did not follow this tendency, showing a rate rising from 2.16 to 6.1 admissions in 2005, which declined sharply in subsequent years (Table 1).

In the Pernambuco microregions, the municipality of Sertão do Moxotó showed highest hospitalization rate, with 1.15/100,000 inhabitants in the period between 1995 and 2008. Among the others, Vale do Pajeú and Salgueiro, located in same microregion, deserve a mention, with rates of 1.03 and 0.61 , respectively. Itapetim (3.88) and Brejinho (1.96), both in the Vale do Ipojuca microregion, together with Itacuruba (3.86) and Sertânia (2.03), located in the Itaparica and Moxotó microregions, respectively, had the highest rates among the towns of Pernambuco (data not shown).

According to SIM, 156,224 deaths presenting Chagas disease as the basic cause occurred between 1980 and 2007 in Brazil, as measured by individual's place of residence. The Northeast region reported 20,472 of these deaths, with 3,144 occurring in Pernambuco. The average mortality rate for the Northeast over the same period was 1.66 deaths from Chagas disease/100,000 inhabitants, lower than in Brazil as a whole, the Central-Western and southern regions, with rates of 3.66, 12.59 and 4.9, respectively. Over the same period, Pernambuco registered 1.53 deaths $/ 100,000$ inhabitants between 1980 and 2007. Even though the Northeastern region ranks third in terms of mortality, the figure has remained constant over the years, while in Brazil as a whole and the central-western and Southern regions, it has seen a substantial decline (Figure 2A). The Central-Western region experienced an particularly marked decrease in mortality over the period studied. This region registered 18 deaths $/ 100,000$ inhabitants in the early 1980 s, falling to 7.2 in 2007 (data not shown).

Tendency analysis for Brazil as a whole, the Northeastern region and Pernambuco shows a decline in mortality to $0.104 / 100,000$ inhabitants per year for the period between 1980 and 2007, which means a mean reduction of 160 deaths per year. However, the northeast did not show the same decline in mortality rate over this period, rather an average growth of $0.013 / 100,000$ inhabitants per year. Pernambuco showed a mortality rate tendency to remain constant, as illustrated in Figure 2B. 


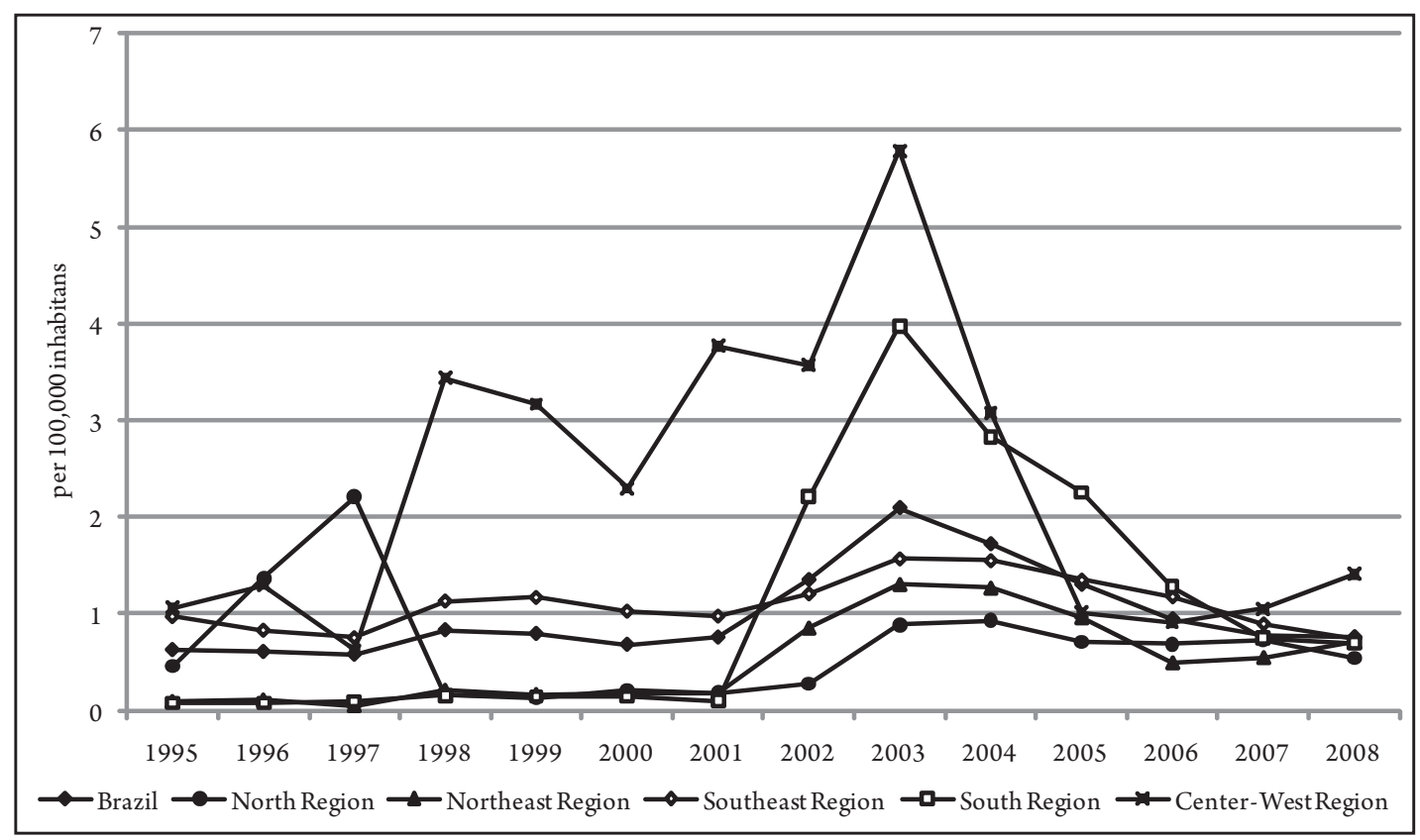

FIGURE 1 - Hospitalization rate for Chagas disease per 100,000 inhabitants - Macroregions of residence (Brazil) - 1995 to 2008.

TABLE 1 - Hospitalization rates for Chagas disease per 100,000 inhabitants from 1995 to 2008 in Northeast second the federal unit of residence.

\begin{tabular}{|c|c|c|c|c|c|c|c|c|c|c|c|c|c|c|c|}
\hline \multicolumn{16}{|c|}{ Year of hospitalization } \\
\hline & 1995 & 1996 & 1997 & 1998 & 1999 & 2000 & 2001 & 2002 & 2003 & 2004 & 2005 & 2006 & 2007 & 2008 & Average \\
\hline $\mathrm{NE}$ & 0.09 & 0.11 & 0.05 & 0.21 & 0.17 & 0.17 & 0.18 & 0.85 & 1.30 & 1.27 & 0.96 & 0.49 & 0.55 & 0.70 & 0.52 \\
\hline MA & 0.08 & 0.02 & 0.02 & 0.07 & 0.07 & 0.04 & 0.02 & 1.28 & 2.67 & 2.42 & 1.69 & 0.63 & 0.13 & 0.24 & 0.69 \\
\hline PI & 0.07 & 0.07 & 0.00 & 0.11 & 0.04 & 0.14 & 0.17 & 1.55 & 2.02 & 1.63 & 0.20 & 0.10 & 0.29 & 0.13 & 0.47 \\
\hline $\mathrm{CE}$ & 0.00 & 0.04 & 0.06 & 0.11 & 0.14 & 0.08 & 0.11 & 1.03 & 1.19 & 0.84 & 0.36 & 0.62 & 0.56 & 0.82 & 0.44 \\
\hline $\mathrm{RN}$ & 0.04 & 0.08 & 0.08 & 0.11 & 0.04 & 0.04 & 0.04 & 1.23 & 1.70 & 1.27 & 3.10 & 2.10 & 3.60 & 2.61 & 1.21 \\
\hline $\mathrm{PB}$ & 0.12 & 0.03 & 0.00 & 0.24 & 0.15 & 0.29 & 0.26 & 0.49 & 0.43 & 0.34 & 0.11 & 0.11 & 0.30 & 0.27 & 0.23 \\
\hline PE & 0.03 & 0.11 & 0.05 & 0.16 & 0.12 & 0.23 & 0.17 & 0.45 & 1.87 & 1.00 & 0.20 & 0.18 & 0.27 & 0.57 & 0.39 \\
\hline $\mathrm{AL}$ & 0.19 & 0.34 & 0.04 & 0.22 & 0.26 & 0.14 & 0.25 & 2.11 & 2.16 & 5.63 & 6.10 & 0.46 & 0.29 & 1.25 & 1.43 \\
\hline SE & 0.00 & 0.06 & 0.06 & 0.00 & 0.12 & 0.00 & 0.11 & 0.76 & 0.85 & 1.00 & 0.51 & 1.15 & 0.74 & 2.00 & 0.56 \\
\hline BA & 0.19 & 0.18 & 0.08 & 0.40 & 0.29 & 0.28 & 0.31 & 0.42 & 0.30 & 0.43 & 0.32 & 0.30 & 0.38 & 0.46 & 0.31 \\
\hline
\end{tabular}

NE: Northeast, MA: Maranhão, PI: Piauí, CE: Ceará, RN: Rio Grande do Norte, PB: Paraíba, PE: Pernambuco, AL: Alagoas, SE: Sergipe, BA: Bahia Data source: DATASUS; SINAN.

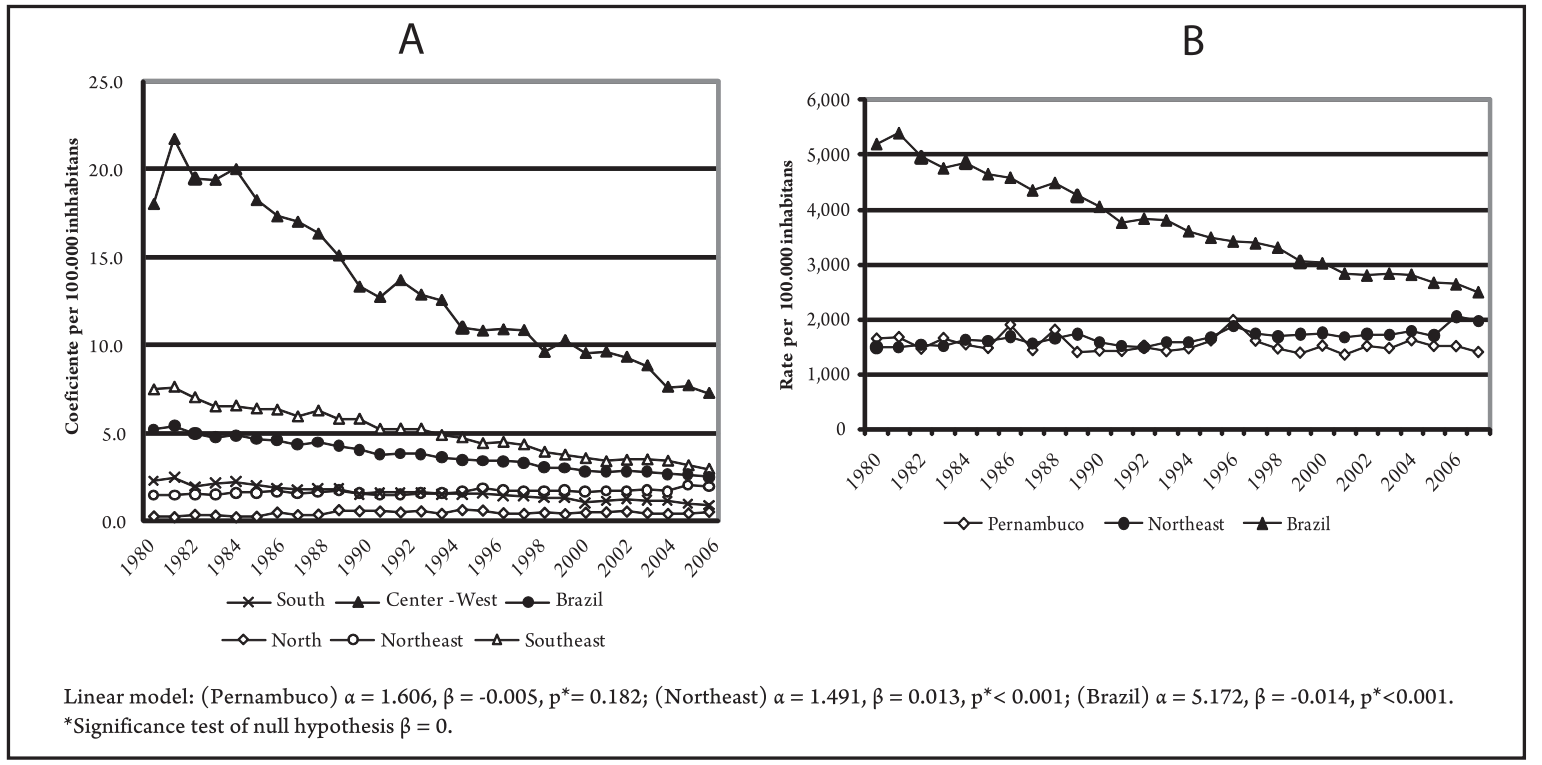

FIGURE 2 - Mortality rates for Chagas disease per 100,000 inhabitants - 1980 to 2007. A: Mortality for Chagas disease (macroregions of residence). B: Mortality rates for Chagas disease per 100,000 inhabitants and parameters of tendency models to Pernambuco, Northeast and Brazil. 
As for admission rates, mortality is concentrated in the rural areas of the State of Pernambuco. The microregions with highest mean rates between 1980 and 2007 were Pajeú and Moxotó, with 5.9 and 3.85 deaths/100,000 inhabitants respectively. Sertânia (11.14), a city in the Sertão do Moxotó; Tuparenatama (11.14), Tabira (8.74), Triunfo (8.59) and Afogados da Ingazeira (8.23), all located in the Vale do Pajeú district, are the five towns in the State of Pernambuco with the highest mortality rates (data not shown).

Comparison of the rates for Chagas disease admissions with mortality rates in the period from 1995 to 2007 shows that the number of reported deaths was higher than number of hospitalizations in the country as a whole and in Pernambuco, every year, except for 2003 (Figure 3).

A total of 2,250 cases of acute Chagas disease were confirmed by SINAN between 2001 and 2006 in Brazil. Pernambuco registered 274 such reports, ranking second in terms of absolute numbers. However, when the mean rate of occurrence was calculated, Pernambuco ranked fifth among the 24 Brazilian States for reports of acute cases, with $0.56 / 100,000$ (Table 2). The present study shows that the states with the highest acute cases rates in this period are located in the northern and northeastern regions of Brazil. Comparing rates in Pernambuco with those for the country as a whole, the state has an above-average rate over this period.

TABLE 2 - Acute case rates for Chagas disease per 100,000 inhabitants - 2001 to 2006.

\begin{tabular}{lrrc}
\hline Federal unit & Total & Population (12/31/2003) & Average rate \\
\hline Brazil & 2,249 & $177,988,694$ & 0.21 \\
\hline Rondônia & 39 & $1,467,878$ & 0.44 \\
\hline Amazonas & 20 & $3,065,413$ & 0.11 \\
\hline Pará & 183 & $6,635,189$ & 0.46 \\
\hline Amapá & 64 & 543,884 & 1.96 \\
\hline Maranhão & 14 & $5,908,622$ & 0.04 \\
\hline Piauí & 148 & $2,936,386$ & 0.84 \\
\hline Ceará & 53 & $7,810,080$ & 0.11 \\
\hline Rio Grande do Norte & 226 & $2,905,634$ & 1.30 \\
\hline Paraíba & 106 & $3,530,367$ & 0.50 \\
\hline Pernambuco & 274 & $8,200,248$ & 0.56 \\
\hline Alagoas & 59 & $2,932,659$ & 0.34 \\
\hline Sergipe & 102 & $1,888,777$ & 0.90 \\
\hline Bahia & 441 & $13,496,480$ & 0.54 \\
\hline Minas Gerais & 84 & $18,657,577$ & 0.08 \\
\hline Espírito Santo & 31 & $3,274,284$ & 0.16 \\
\hline Rio de Janeiro & 42 & $14,956,032$ & 0.05 \\
\hline São Paulo & 36 & $38,973,449$ & 0.02 \\
\hline Paraná & 20 & $9,960,970$ & 0.03 \\
\hline Santa Catarina & 73 & $5,646,692$ & 0.22 \\
\hline Rio Grande do Sul & 159 & $10,562,009$ & 0.25 \\
\hline Mato Grosso do Sul & 27 & $2,184,124$ & 0.21 \\
\hline Mato Grosso & 12 & $2,674,414$ & 0.07 \\
\hline Goiás & 35 & $5,354,165$ & 0.11 \\
\hline Distrito Federal & $2,211,594$ & 0.01 \\
\hline & & &
\end{tabular}

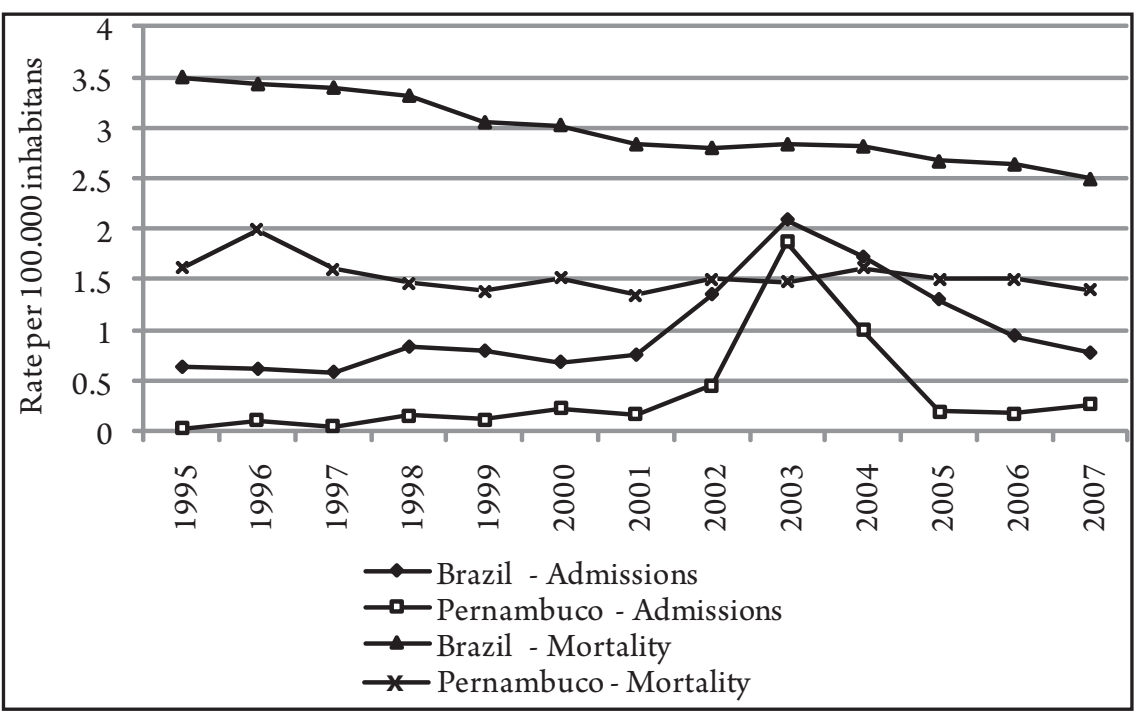

FIGURE 3 - Rates of hospitalizations and mortality for Chagas disease per 100,000 inhabitants in Pernambuco and Brazil - 1995 to 2007.

\section{DISCUSSION}

The peak admissions rate in 2003 in Brazil can be explained by the emphasis placed on Chagas disease in the $21^{\text {st }}$ century, a period during which the country received certification for having eliminated the transmission of the disease by T. infestans ${ }^{10}$. This may have triggered a greater commitment on the part of health professionals for accurate reporting of the cause of admissions to DATASUS/MS. However, one-off assessments in States and municipalities need to be conducted to clarify what other factors could be responsible for this increase in the reporting of admissions for Chagas disease.

Owing to the difficulty in diagnosing Chagas disease in its acute phase, the majority of reported hospitalizations probably represent individuals who acquired Chagas disease many years previously. Thus, the concentration of admissions in rural parts of Pernambuco indicates the importance of this region for the transmission of this disease in the state as a whole. However, AIH presents a number of disadvantages, since the main purpose of the database is to ensure 
payment for admissions to SUS hospitals. One of these is the possible failure to complete the form, leading to under-reporting and incorrect registration of the cause of hospitalization or absence of information relating to repeated hospitalizations.

In view of the period that has elapsed since the introduction of policies to control transmission, along with slow disease progress, a decline in the number of deaths would be expected. This profile can be confirmed nationally, but Pernambuco and the Northeastern region have not shown reductions in reports of deaths from the disease. This suggests a hypothesis that the control and prevention of Chagas disease in this region has been negligent, resulting in the emergence of new cases and a tendency for the mortality rate to remain constant in the long-term.

Given the fact that Chagas disease has a slow chronic progression, reported deaths are mostly related to an infection acquired many years previously. This suggests that number of new cases in the northeast may have remained constant or even increased. Dias et al highlighted the high number of vector species present in the Northeast, corresponding to $50 \%$ of those registered in Brazil ${ }^{6}$. Possible failures or difficulties in controlling secondary vector species, together with oral and congenital routes of infection, could be contributing to the maintenance of T. cruzi transmission in this region.

It should be noted that deaths reported in Pernambuco according to patient place of residence will probably not reveal the true values for local populations, since compiling deaths according to place of residence means that data will not include individuals who acquired Chagas disease in their home state and who died in another Federal Unit. Neither will it exclude deaths from Chagas disease of patients who came to reside in that state during the period studied. While investigating mortality rates for the disease from 1981 to 1998 in Brazil, Drumond \& Marcopilo ${ }^{16}$ verified that $32 \%$ of those who died were born in states other than their state of residence, which reflects the extensive internal migration that occurred during the period. Data analysis by place of infection may allow this bias to be corrected; however, many carriers only discover that they have the disease long after they initially acquired the parasite and vast majority does not have precise information concerning the circumstances of their contact with T. cruzi.

It is important remember that interpretation of mortality data provided by DATASUS must consider important interferences: a) underreporting; b) errors in the completion of death certificates; c) failures in the coverage system and transmission information, which varies according to the region and state; $d$ ) and percentage of deaths due to undefined causes, which also varies according to the Federal Unit ${ }^{17,18}$, leading to the diminished reliability of these data. However, the mortality database, SIM, has undergone improvements since its implementation in 1975, including reducing the amount of ignored or incomplete information ${ }^{19}$, making the results obtained in this study worthy of note.

Regarding the data obtained after comparing rates for admissions with mortality, it is improbable that such a large number of patients died without receiving hospital care. These data suggest the presence of errors in AIH completion, leading to under-reporting of SIH data on admissions to hospital for Chagas disease. These reported hospitalizations still show a bias of not informing cases of repeated patient admissions in the period studied.

It is significant that, during $9^{\text {th }}$ Meeting of the Intergovernmental Commission for the Southern Cone Initiative, analysis of FUNASA proposals regarding vector transmission of Chagas disease, Pernambuco numbered among the states that should receive certification by end of $2000^{20,21}$, while Brazil as a whole only received certification in $2006^{10}$.

All the databases SIM and SIH, SINAN have failures. These included duplicate registers and lack of table standardization, which were attenuated by the replacement of SINAN-DOS by the SINANWindows program ${ }^{22}$, which was implanted in 2007 in the SINAN NET. However, failures in the preparation and the lack of knowledge of the users of this and other DATASUS information systems endures, forming the greatest obstacle to optimizing the use of these tools.

Importantly, acute Chagas disease became a notifiable disease for Municipal and State Health Departments and the Ministry of Health in 2003 (Portaria 2.325/GM, 2003, December, 8) ${ }^{23}$. Thus, the number of cases reported to SINAN in the years prior this ordinance probably does not express wholly accurate values.

Examination of the data collected for this study has shown that data for Pernambuco does not reflect that for Brazil as a whole, regarding the control of Chagas disease. The state shows a much higher acute cases rate than the national rate for the period. Even more alarming is the fact that the decline in national mortality rate for Chagas disease has failed to emerge in the State of Pernambuco and the northeastern region. Data presented and discussed in this paper therefore demonstrate significant shortcomings in the public system for the control, prevention and treatment of Chagas disease. Thus, even with successful transmission control campaigns, monitoring for this disease is still required in the northeastern region, particular in Pernambuco.

\section{CONFLICT OF INTEREST}

The authors declare that there is no conflict of interest.

\section{FINANCIAL SUPPORT}

This research received support from the Conselho Nacional de Desenvolvimento Científico e Tecnológico ( $\mathrm{CNPq}$ ) and from the Coordenação de Aperfeiçoamento de pessoal de Nível Superior (CAPES). Y.M. Gomes and W.V. Souza are fellows of CNPq, n 306427/2006-0 and no 307484/2007-6, respectively. V.M.B. Lorena is a postdoctoral fellow of CNPq. S.C.M. Braz is a candidate for Master's degree in Public Health (CPqAM-Fiocruz) and is a CNPq fellow (n 133106/2009-8). M.F.A.D. Melo was Capes fellow for duration of this research.

\section{REFERENCES}

1. Coura JR, Dias JCP. Epidemiology control and surveillance of Chagas disease 100 years after its discovery. Mem Inst Oswaldo Cruz 2009; 104:31-40.

2. Schmunis GA. Enfermedad de Chagas em um mundo global. In: AC Silveira, editor. La enfermedad de Chagas a La puerta de los 100 años del conocimiento de uma endemia americana ancestral. Buenos Aires: Fundación Mundo Sano; 2007. p. 251-266.

3. Castro Filho J, Silveira AC. Distribuição da doença de Chagas no Brasil. Rev Bras Malariol Doencas Trop 1984; 31:85-97.

4. Fiusa-Lima JT, Silveira AC. Controle da transmissão e inquérito sorológico nacional. In: JR Cançado, M Chuster, editors. Cardiopatia Chagásica. Belo Horizonte: Fundação Carlos Chagas; 1984. p. 371-380.

5. Silveira AC, Feitosa VR, Borges R. Distribuição de triatomíneos domiciliados no período 1975/1983 no Brasil. Rev Bras Malariol Doencas Trop 1984; 36:15-312. 
6. Dias JCP, Machado EMM, Fernandes AL, Vinhaes MC. Esboço geral e perspectivas da doença de Chagas no Nordeste do Brasil. Cad Saude Publica 2000; 16:13-34.

7. Melo AS, Lorena VMB, Moraes AB, Pinto MBA, Leão SC, Soares AKA, et al. Prevalência de infecção chagásica em doadores de sangue no estado de Pernambuco, Brasil. Rev Bras Hematol Hemoter 2009; 31: 69-73.

8. Dias JCP. Control of Chagas disease in Brazil. Parasitol Today 1987; 3:336-341.

9. Schofield CJ, Dias JCP. Souther cone initiative against Chagas disease. Adv Parasitol 1999; 42:1-27.

10. Dias JCP. Chagas disease: successes and challenges. Cad Saude Publica 2006; 22:2020-2021.

11. Oliveira Filho AM. Differences of susceptibility of five triatomine species to pyrethroid insecticides- implications for Chagas disease vector control. Mem Inst Oswaldo Cruz 1999; 94:425- 428.

12. Coura JR, Junqueira ACV, Fernandes O, Valente SAS, Miles MA. Emerging Chagas disease in Amazonian Brazil. Trends Parasitol 2002; 18:171-176.

13. World Health Organization. Guia para Vigilância, prevenção, controle e manejo clínico da doença de Chagas Aguda transmitida por alimentos. Geneva: Organização Pan Americana de Saúde; 2009.

14. Valente SAS, Valente VC, Pinto AYN, César MJB, Santos MP, Miranda COS, et al. Analysis of an acute Chagas disease outbreak in the Brazilian Amazon: human cases, triatomines, reservoir mammals and parasites. Trans Royal Soc Trop Med Hyg 2009; 103:291-297.

15. Gontijo ED, Andrade GMQ, Santos SE, Galvão LMC, Moreira EF, Pinto FS, et al. Triagem Neonatal da infecção pelo Trypanosoma cruzi em Minas Gerais, Brasil: transmissão congênita e mapeamento das áreas endêmicas. Epidemiol Serv Saude 2009; 18:243-254.

16. Drumond JAG, Marcopilo LF. Migração interna e a distribuição da mortalidade por doença de Chagas, Brasil, 1981/1998. Cad Saude Publica 2006; 22:21312140 .

17. Mello Jorge MHP. Registro dos eventos vitais: sua importância em saúde pública. Série divulgação n 5 . São Paulo: Centro da Organização Mundial de Saúde para Classificação de Doenças em Português; 1996.

18. Mameri CP. Tendências populacionais: óbitos por causas mal definidas. Conjuntura demográfica 1990; 10:7-10.

19. Mello Jorge MHP, Laurenti R, Gotlieb SLD. Análise da qualidade das estatísticas vitais brasileiras: a experiência de implantação do SIM e do SINASC. Cienc Saude Colet 2007; 12:643-654.

20. World Health Organization. Brazil to be declared free of Chagas disease. TDR News 2000a; 62:14.

21. World Health Organization. Chagas disease, Brazil - Interruption of transmission. Wkly Epidemiol Rec 2000b; 75:153-155.

22. Laguardia J, Domingues CMA, Carvalho C, Lauerman CR, Macário E, Glatt R. Sistema de Informação de Agravos de Notificação (SINAN): desafios no desenvolvimento de um sistema de informação em saúde. Epidemiol Serv Saude 2004; 13:135-146.

23. Ministério da Saúde. Portaria no 2.325/GM. Dispõe a relação de doenças de notificação compulsória para todo território brasileiro (Dec 8, 2003). Available from: http://dtr2001.saude.gov.br/sas/PORTARIAS/Port2003/GM/GM2325.htm/. 